\title{
INTERFERENSI FONOLOGIS BAHASA MELAYU PATTANI DALAM BERBAHASA INDONESIA MAHASISWA THAILAND DI UNIVERSITAS MUHAMMADIYAH SURAKARTA
}

\author{
(THE PHONOLOGICAL INTERFERENCE OF MALAY PATTANI LANGUAGE IN \\ USING INDONESIAN LANGUAGE OF THAI STUDENTS AT THE UNIVERSITY OF \\ MUHAMMADIYAH SURAKARTA)
}

\author{
Aseeyah Kuwing \\ Jabatan Bahasa Melayu Universiti Fatoni \\ Pos-el:as.asiyah@gmail.com
}

Diterima: Februari 2017; Direvisi: 17 Oktober 2017; Disetujui: 23 Oktober 2017

\begin{abstract}
The purpose of this study is to describe a form ofphonological interference of Malay Pattani language in Indonesian language of Thai students at the University of Muhammadiyah Surakarta. This type of research is qualitative descriptive. The data source of this research is Thai students at the University of Muhammadiyah Surakarta. Data were collected by listening, recording, and interviewing. Data were analyzed using match method with translational type and contrastive analysis method. There is one thingaddressed in this study; Existence of phonological interference of Malay Pattani language in Indonesian language of Thai students at the University of Muhammadiyah Surakarta. The study shows that (a) Interference phonological elements found in the phoneme replacement, phoneme deletion, substitution of syllables, and syllables deletion. (b) Interference also found in the lexicon of nouns, verbs, adjectives, pronouns, bookmark, adverbs, prepositions and question words. (c)syntaxInterference found in the type of news sentences, interrogative sentence, and imperative sentences.
\end{abstract}

Keywords:interference, Malay Pattani language, Indonesian language

\begin{abstract}
Abstrak
Penelitian ini bertujuan untuk mendeskripsikan wujud interferensi fonologi bahasa Melayu Pattani dalam berbahasa Indonesia mahasiswa Thailand di Universitas Muhammadiyah Surakarta. Jenis penelitian ini adalah deskriptif kualitatif.Sumber data penelitian ini adalah mahasiswa Thailand di Universitas Muhammadiyah Surakarta. Teknik pengumpulan data dilakukan dengan cara simak, rekam, dan wawancara. Teknik analisis data menggunakan metode padan jenis translasional dan metode analisis kontrastif. Ada satu hal yang perlu disampaikan pada penelitian ini yaituwujud interferensi fonologi bahasa Melayu Pattani dalam berbahasa Indonesia mahasiswa Thailand di Universitas Muhammadiyah Surakarta, yang ditemukan tiga jenis interferensi, yaitu(a) interferensi fonologi terdapat pada unsur penggantian fonem, pelesapan fonem, penggantian suku kata, dan pelesapan suku kata; (b) interferensi leksikon terdapat pada kata benda, kata kerja, kata sifat, kata ganti, kata penunjuk, kata keterangan, kata depan, dan kata tanya; dan (c) interferensi sintaksis terdapat pada jenis kalimat berita, kalimat tanya, dan kalimat perintah.
\end{abstract}

Kata kunci: interferensi, Bahasa Melayu Pattani, Bahasa Indonesia 


\section{Pendahuluan}

Bahasa merupakan alat untukmenghubungkan atau interaksi individu dengan individu.Manusia sejak ia bangun sampai ia memejamkan mata selalu berurusan dengan bahasa dalam arti selalu mempergunakan dan bergaul dengan bahasa. Seandainya kita rajin mencatat kata dan kalimat yang telah kita gunakan dan manfaatkan setiap hari alangkah banyaknya kata dan kalimat itu. Tentu ada kata atau kalimat yang berulangulang muncul dalam pembicaraan kita. Sebaliknya, ada kata-kata maupun kalimat yang dua atau tiga hari baru muncul lagi. Setiap kali manusia menggunakan bahasa selalu dalam bentuk berbicara, mendengar, menulis, dan membaca. Oleh karena itu, segala kehidupan atau tingkah lakumanusia diatur dengan menggunakan bahasa (Pateda, 1987:1).

Bahasa Melayu dalam perkembangannya berabad-abad yang lalu telah menyebar ke seluruh wilayah Nusantara dan Asia Tenggara, bahkan juga ke tempat yang lebih jauh. Akibatnya, terbentuklah berbagai dialek areal dan dialek sosial serta ragam-ragam bahasa menurut keperluan. Malah pada abad ke20, telah terlahir empat buah bahasa negara, yaitu bahasa Indonesia di negara Republik Indonesia, bahasa Malaysia di Kerajaan Malaysia, bahasa Brunei di
Kesultanan Brunei Darussalam, dan bahasa Melayu Singapura di Republik Singapura (Zamberi,1994:243).

Bahasa Melayu Pattani (BMP) atau dikenal juga dengan dialek Melayu Pattani merupakan bahasa perantaraan dalam kalangan masyarakat Melayu di tiga wilayah selatan Thai. Sepanjang masaberdirinya kerajaan Melayu-Islam Patani, bahasa Melayu mencapai tahap kegemilangannya dan berperan sebagai lingua franca atau bahasa perantaraan dalam kalangan penduduk setempat dan para pedagang yang menyebarkan Islam pada abad tersebut. Zamberi (1994:243) menyatakan bahwa bahasa Melayu Patani telah menjadi bahasa ilmu dan berjaya meletakkan Patani sebagai pusat tamadun kesusasteraan Melayu Islam menerusi penghasilan karya kitab-kitab agama oleh para ulama.

Bahasa Indonesia adalah bahasa yang sekaligus menyandang tiga buah status, yaitu sebagai bahasa persatuan, sebagai bahasa nasional, dan sebagai bahasa negaramempunyai rangkaian sejarah yang sangat panjang. Keberadaan awal bahasa Indonesia, yang sebelum Sumpah Pemuda 28 Oktober 1928 bernama bahasa Melayu, ditandai dengan bukti berupa inskripsi atau prasasti yang banyak bertebaran di Pulau Sumatera, Pulau Jawa, Pulau Bangka, dan 
Semenanjung Malaya (yang sekarang menjadi bagian dari Negara Malaysia).

Data Bahasa Melayu yang berasal dari zaman Sriwijaya terdapat pada prasasti Kedukan Bukit yang berangka tahun caka 605 (683 M) dan Prasasti Talang Tuo yang berangka tahun caka 606 (684 M). Kedua prasasti itu terdapat di sekitar Kota Palembang sekarang. Prasasti lain yang sezaman dengan kedua prasasti tersebut terdapat di Pulau Bangka (Prasasti Kota Kapur), di daerah Jambi (Prasasti Karang Berahi), dan di Lampung Selatan (Prasasti Palas Pasemah). Sementara prasasti-prasasti yang lain berangka tahun yang lebih muda.

Berkaitan dengan sejarah bahasa Melayu Pattani dan bahasa Indonesia,dapat diketahui bahwa bahasa tersebut berasal dari satu rumpun bahasa Melayu. Oleh karena itu, Bahasa Indonesia (BI) banyak dipengaruhi oleh BMP yang berstatus sebagai bahasa mayoritas yang digunakan oleh masyarakat Melayu di empat provinsi di Thailand Selatan dalam berkomunikasi umum dan juga dalam upacara-upacara tertentu. Dengan latar belakang tersebut,dapat diperkirakan bahwa terjadi interferensi BMP dalam penggunaan Berbahasa Indonesia oleh mahasiswa Thailand dalam komunikasi sehari-hari mereka. Fenomena interferensi yang terjadi yaitu pada leksikal BI terhadap
BMP. Masalah tersebut merupakan satu masalah yang menarik untuk diteliti atau dikaji dengan judul Interferensi Bahasa Melayu Pattani dalam Berbahasa Indonesia Mahasiswa Thailand di Universitas Muhammadiyah Surakarta (UMS)”.

\section{Kerangka Teori}

Istilah sosiolinguistik terdiri atas dua unsur, yaitu sosio dan linguistik. Kita mengetahui arti linguistik, yaitu ilmu yang mempelajari atau membicarakan bahasa, khususnya unsur-unsur bahasa (fonem, morfem, kata, kalimat) dan hubungan antara unsur-unsur itu (struktur), termasuk hakikat dan pembentukan unsur-unsur itu. Unsur sosio adalah seakar dengan sosial, yaitu yang berhubungan dengan masyarakat, kelompok-kelompok masyarakat, dan fungsi-fungsi kemasyarakatan. Jadi, sosiolinguistik ialah studi atau pembahasan dari bahasa sehubungan dengan penutur bahasa itu sebagai anggota masyarakat. Boleh juga dikatakan bahwa sosiolinguistik mempelajari dan membahas aspek-aspek kemasyarakatan bahasa, khususnya perbedaan-perbedaan (variasi) yang terdapat dalam bahasa yang berkaitan dengan faktor-faktor kemasyarakatan (Nababan, 1991:2).

Istilah interferensi pertama kali digunakan oleh Weireich dalam Ohoiwutun (1996:72) dalam "Languages in Contact" 
untuk menyebut adanya perubahan sistem suatu bahasa sehubungan dengan adanya persentuhan bahasa tersebut dengan unsurunsur bahasa lain yang dilakukan oleh dwibahasawan. Ohoiwutun menganggap interferensi sebagai gejala penyimpangan dari norma-norma kebahasaan yang terjadi pada pengguna bahasa seorang penutur sebagai akibat dari kontak bahasa ibu (selanjutnya disebut B1) dan bahasa asing (selanjutnya disebut B2).

Chaer dan Agustina (2004:162--165) menyatakan bahwa interferensi fonologis terjadi apabila penutur mengungkapkan kata-kata dari suatu bahasa dengan menyisipkan bunyi-bunyi bahasa dari bahasa lain. Interferensi fonologis dibedakan menjadi dua macam, yaitu interferensi fonologis pengurangan huruf dan interferensi fonologis pergantian huruf.

Interferensi morfologis terjadi apabila dalam pembentukan katanya suatu bahasa menyerap afiks-afiks bahasa lain. Penyimpangan struktur itu terjadi kontak bahasa antara bahasa yang sedang diucapkan (bahasa Indonesia) dengan bahasa lain yang juga dikuasainya (bahasa daerah atau bahasa asing).

Interferensi sintaksis terjadi apabila struktur bahasa lain (bahasa daerah, bahasa asing, dan bahasa gaul) digunakan dalam pembentukan kalimat bahasa yang digunakan. Penyerapan unsur kalimatnya dapat berupa kata, frase, dan klausa. Interferensi sintaksis seperti ini tampak jelas pada peristiwa campur kode.

Interferensi leksikal terjadi apabila adanya pencampuran bahasa pertama yang menjadi serpihan dalam bahasa kedua, baik kata maupun frasa bahasa pertama. Weinrich (1970:64--65) menyatakan bahwa faktor yang menyebabkan terjadinya interferensi yaitu kedwibahasaan peserta tutur. Hal ini merupakan pangkal terjadinya interferensi dan berbagai pengaruh lain dari bahasa sumber, baik dari bahasa daerah maupun bahasa asing. Tipisnya kesetiaan dwibahasawan terhadap bahasa penerima cenderung akan menimbulkan sikap kurang positif. Perbendaharaan kata suatu bahasa pada umumnya hanya terbatas pada pengungkapan berbagai segi kehidupan yang terdapat di dalam masyarakat yang bersangkutan serta segi kehidupan lain yang dikenalnya. Kosakata dalam suatu bahasa yang jarang digunakan cenderung akan menghilang. Sinonim dalam pemakaian bahasa mempunyai fungsi yang cukup penting. Prestise bahasa sumber dapat mendorong timbulnya interferensi. Kebiasaan dalam bahasa ibu terbawa pada bahasa penerima yang sedang digunakan. Hal ini umumnya terjadi karena kurangnya kontrol bahasa dan kurangnya penguasaan terhadap bahasa penerima. 
Joko (2011) menjelaskan bahwa proses interferensi dapat terjadi dalam segala tataran kehidupan, termasuk dalam penelitianini, yaitu interferensi bahasa Indonesia dalam acara berita berbahasa Jawa "Kuthane Dhewe" di TV Borobudur Semarang. Lebih lanjut dijelaskan bahwa ada empat macam interferensi, yaitu (1) interferensi tataran fonologi, (2) interferensi tataran leksikal,

(3) interferensi tataran morfologi, dan (4) interferensi tataran sintaksis.

Dari hasil penelitian Annura (2013), diketahui bahwa mahasiswa sastra Indonesia yang telah mempunyai bekal keterampilan berbahasa Indonesia masih sering melakukan interferensi dalam proses komunikasi formal. Interferensi berbahasa pada penelitian ini digolongkan dalam tiga bidang kajian, yakni fonologi, morfologi, dan leksikal.

Dalam penelitian Masrurah (2000), dijelaskan bahwa di antara berbagai masalah bahasa yang dihadapi yang akhirakhir ini mendapat perhatian cukup besar dalam masyarakat, tetapi sampai kini belum diteliti secara sungguh-sungguh oleh para ahli bahasa di Indonesia adalah peristiwa alternasi atau pemakaian bahasa secara silih berganti antara bahasa Indonesia dan bahasa daerah dalam satu kalimat, paragraf, atau wacana. Penelitian ini berhasil mengumpulkan data sosiolinguistik dalam bentuk data morfologis sebanyak 109 buah, 39 yang diolah menurut sifat-sifat morfemnya, kemudian ditranskripsikan untuk menemukan ruas-ruas asalnya.

Penelitian Laura, dkk (2014) berhasil mengidentifikasi hal-hal sebagai berikut. Pertama, ditemukan adanya peristiwa alih kode. Kedua, ditemukan peristiwa campur kode. Ketiga, ditemukan interferensi bahasa Jawa dan bahasa Betawi pada tuturan bahasa Indonesia yang terjadi pada tataran fonologi, sintaksis, dan morfologi.

Stanislaus (2015) menyatakan bahwa mahasiswa Manggarai Timur yang ada di Kota Malang masih menggunakan beberapa kosa kata bahasa Manggarai Timur dalam komunikasi bahasa Indonesia. Ada dua macam interferensi yang mereka lakukan, yaitu interferen simorfologis dan interferensi sintaksis.

\section{Metode Penelitian}

Jenis penelitian ini adalah deskriptif kualitatif. Subjek dalam penelitian ini adalah Mahasiswa Thailand S1 di Universitas Muhammadiyah Surakarta. Data dalam penelitian ini adalah penggunaan BMP dalam BI dengan menggunakan teknik simak yaitu peneliti terlibat langsung dan ikut serta dalam pembicaraan informan serta memperhatikan dan mendengar kemudian diikuti dengan teknik rekam dan diakhiri dengan teknik wawancara terhadap 
mahasiswa Thailand yang menggunakan BMP dalam berkomunikasi mereka.

Objek penelitian merupakan sasaran yang akan menjadi fokus penelitian. Pada penelitian ini, peneliti memilih objek penelitian yaitu mahasiswa Thailand di UMS yang berbahasa Melayu Patani.

Data adalah semua informasi atau bahan yang disesuaikan oleh alam yang harus dicari atau dikumpulkan dan dipilih oleh peneliti. Dalam hal ini, data penelitian ini adalah semua tuturan bahasa Melayu Patani yang dituturkan oleh mahasiswa Thailand di UMS yang mengandung inerferensi dan penyebabnya. Sumber data dalam penlitian ini berasal dari informan yaitu mahasiswa Thailand di UMS yang dipilih sebagai pengguna bahasa induk dalam ranah lingkungan yang bukan asli dari lingkup bahasa induk yaitu BMP.

Dalam penelitian ini, peneliti menguji kredibilitas data dengan cara mengecek data yang telah diperoleh melalui beberapa sumber yaitu menguji kredibilitas data tentang wujud interferensi bahasa Melayu Pattani dalam bahasa Indonesia yang dituturkan oleh mahasiswa Thailand di UMS strata satu dengan mahasiswa Thailand lainnya.

Penelitian ini menggunakan metode padan jenis translasional karena metode ini alat penentunya bahasa atau selain lingual yang sesuai dengan BI dengan BMP. Penelitian ini meneliti tentang penggunaan bahasa seseorang penutur sebagai akibat dari kontak bahasa ibu dan bahasa asing.

\section{Hasil dan Pembahasan}

Wujud interferensi BMP dalam berbahasa Indonesia mahasiswa Thailand di UMS, yaitu interferensi fonologis. Interferensi fonologis merupakan suatu proses yang berusaha menerangkan perubahan-perubahan morfem atau kata berdasarkan ciri-ciri pembeda secara fonetis. Perubahan biasanya terjadi seperti penghilangan fonem pada awal, tengah, dan akhir atau melalui proses penggantian fonem, pelesapan fonem, penggantian suku kata, dan pelesapan suku kata. Berikut adalah wujud interferensi fonologis dalam berbahasa Indonesia mahasiswa Thailand di UMS.

\subsection{Penggantian Fonem}

Penggantian fonem merupakan proses pergantian fonem yang seartikulasi, fonem yang sama dijadikan tidak sama. Perubahan biasanya terjadi pada fonem awal, tengah, dan akhir. Fonem dalam BI yang diganti dengan fonem BMP dinyatakan pada tabel berikut. 
Tabel 1

\begin{tabular}{|c|c|c|}
\hline Fonem & Kata BI & Kata BMP \\
\hline$/ \mathrm{a} / \rightarrow / \mathrm{J} /$ & kita & kito \\
\hline$/ \mathrm{r} / \rightarrow / \gamma /$ & hari & hari \\
\hline
\end{tabular}

Interferensi tersebut bisa dilihat pada data berikut.

Deskripsi Data 1

Kalimat Berbahasa Indonesia

Mahasiswa Thaialand (MT) : Jam waps kito no? gi?

Kalimat Bahasa Melayu Pattani : Puko waps kits no? gi?

Kalimat Bahasa Indonesia $\quad$ : Jam berapa kita hendak pergi?

Pada data di atas, terdapat dua bunyi yang sama atau mirip menjadi interferensi pada penggunaan BMP dalam bunyi yang tidak sama atau berbeda yaitu berbahasa Indonesia mahasiswa Thailand pada kata [kits] (BMP) dengan di UMS, yaitupada kata [kito] $(B M P)$ dan menggunakan bunyi / / pada fonem akhir. [kita] (BI). Dari data tersebut, terjadi Sementara, kata dalam BI [kita] interferensi fonologi melalui proses menggunakan fonem /a/ pada suku kata disimilasi, yaitu ada perubahan bunyi dari akhir.

Deskripsi Data 2

Kalimat Berbahasa Indonesia

Mahasiswa Thailand (MT)

: Haji ning ka? ta? do? ngaji.

Kalimat Bahasa Melayu Pattani $\quad$ : Hayi ning ka? ta? do? ngaji.

Kalimat Bahasa Indonesia $\quad$ : Hari ini kakak tidak ada kuliah.

Pada data di atas, terdapat pada fonem akhir. Sementara, kata dalam interferensi pada penggunaan BMP dalam berbahasa Indonesia mahasiswa Thailand BI [hari] menggunakan fonem $/ r /$ pada suku kata akhir.

di UMS pada kata [hayi] $(B M P)$ dan [hari]

\subsection{Pelesapan Fonem}

$(B I)$. Dari data tersebut, terjadi interferensi fonologis melalui proses disimilasi yaitu ada perubahan bunyi dari dua bunyi yang sama atau mirip menjadi bunyi yang tidak sama atau berbeda yaitu pada kata [hayi] $(B M P)$ dengan menggunakan bunyi $/ y /$

Pelepasan fonem merupakan proses penghilangan fonem yang seartikulasi, fonem yang sama dijadikan tidak sama. Perubahan biasanya terjadi pada fonem awal, tengah, dan akhir. Fonem dalam BI 
yang dilesapkan dengan fonem dalam BMP dinyatakan pada tabel berikut.

Tabel 2

\begin{tabular}{|c|c|c|}
\hline Fonem & Kata BI & Kata BMP \\
\hline$/ \mathrm{n} / \rightarrow / \varnothing /$ & dengan & denga \\
\hline$/ \mathrm{l} / \rightarrow / \varnothing /$ & akal & $\mathrm{a} k a$ \\
\hline$/ \mathrm{b} / \rightarrow / \varnothing /$ & lembu & lemu \\
\hline$/ \mathrm{b} / \rightarrow / \varnothing /$ & berjalan & jale \\
\hline
\end{tabular}

Pelesapan tersebut bisa dilihat pada data berikut.

Deskripsi Data 3

Kalimat Berbahasa Indonesia

Mahasiswa Thailand (MT)

: Manusis ads aka pikeye.

Kalimat Bahasa Melayu Pattani : Manusis ads aka pikeye.

Kalimat Bahasa Indonesia

: Manusia mempunyai akal pikiran.

Pada data di atas, terdapat interferensi fonologi berupa penghilangan bunyi /l/ pada penggunaan BMP dalam berbahasa pada suku kata akhir, sementara kata dalam Indonesia mahasiswa Thailand di UMS, BI [akal] mempunyai fonem $/ l /$ pada suku yaitupada kata $[a k a](B M P)$ dan $[a k a l](B I)$. kata akhir.

Dari data tersebut, terjadi interferensi

Deskripsi data4

Kalimat Berbahasa Indonesia

Mahasiswa Thailand (MT)

: Hayi yabu ning, Hasuna kəno gi jupo? donga dosen.

Kalimat Bahasa Melayu Pattani : Hayi yabu ning, Hasuna kəno gi jups? donga acan.

Kalimat Bahasa Indonesia $\quad$ : Hari rabu Hasuna harus pergi berjumpa dengan dosen.

Pada data di atas, terdapat interferensi pada penggunaan BMP dalam berbahasa Indonesia mahasiswa Thailand di UMS, yaitupada kata $[$ dənga $](B M P)$ dan [dengan] $(B I)$. Dari data tersebut, terjadi interferensi fonologi berupa penghilangan bunyi /n/ pada suku kata akhir, sementara kata dalam BI [dengan] mempunyai fonem /n/ pada suku kata akhir.

\subsection{Penggantian Suku Kata}

Penggantian suku kata merupakan proses pergantian suku kata yang 
seartikulasi, fonem yang sama dijadikan tidak sama. Perubahan biasanya terjadi seperti fonem awal, tengah, dan akhir.
Penggantian suku kata dengan fonem dalam BMP dinyatakan pada tabel berikut.

Tabel 3

\begin{tabular}{|c|c|c|}
\hline Suku Kata & Kata BI & Kata BMP \\
\hline$/ \mathrm{lan} / \rightarrow / \mathrm{l} /$ & jalan & jal $\varepsilon$ \\
\hline$/ \mathrm{lam} / \rightarrow / \mathrm{l} /$ & dalam & dal $\varepsilon$ \\
\hline$/ \mathrm{b} / \rightarrow / \mathrm{m} /$ & lembu & lemmu \\
\hline$/ \mathrm{b} / \rightarrow / \mathrm{j} /$ & berjalan & jjale \\
\hline
\end{tabular}

Penggantian suku kata tersebut bisa dilihat pada data berikut.

Deskripsi data 5

Kalimat Berbahasa Indonesia

Mahasiswa Thailand (MT)

: Hati-hati dijalk.

Kalimat Bahasa Melayu Pattani

: Winga? di jale.

Kalimat Bahasa Indonesia : Hati-hati dijalan.

Pada data di atas, terdapat interferensi kata yaitu pada kata [jale] $(B M P)$, diganti pada penggunaan BMP dalam berbahasa suku kata $/ l \varepsilon /$ pada suku kata akhir, Indonesia mahasiswa Thailand di UMS, sementara kata dalam BI [jalan] yaitu pada kata [jale] (BMP) dan [jalan] menggunakan suku kata /lan/ pada suku $(B I)$. Dari data tersebut, terjadi interferensi kata akhir. fonologi melalui proses penggantian suku

Deskripsi data 6

Kalimat Berbahasa Indonesia

Mahasiswa Thailand (MT)

Kalimat Bahasa Melayu Pattani

Kalimat Bahasa Indonesia
: Wa? makalah dale bahaso gapo?

: Wa? ngan dale bahaso gapo?

: Menggunakan bahasa apa dalam membuat makalah?
Pada data di atas, terdapat interferensi pada penggunaan BMP dalam berbahasa Indonesia mahasiswa Thailand di UMS, yaitupada kata $[$ dale] $(B M P)$ dan [dalam] (BI). Dari data tersebut, terjadi interferensi fonologi melalui proses penggantian suku kata yaitu pada kata $[$ dale] $(B M P)$, diganti suku kata /le/pada suku kata akhir, sementara kata dalam BI [dalam] menggunakan suku kata/lam/ pada suku kata akhir. 


\subsection{Pelesapan Suku Kata}

Pelesapan suku kata merupakan proses penghilangan suku kata seartikulasi.
Pelesapan ini biasanya terjadi pada fonem awal. Fonem dalam BI yang suku kata dilesapkan dalam dalam BMP dinyatakan pada tabel berikut.

\section{Tabel 4}

\begin{tabular}{|c|c|c|}
\hline Suku Kata & Kata BI & Kata BMP \\
\hline$/$ kakak $/ \rightarrow /$ ka?/ & Kakak & ka? \\
\hline$/$ pergi $/ \rightarrow /$ gi/ & Pergi & gi \\
\hline
\end{tabular}

Pelesapan tersebut bisa dilihat pada data berikut.

\section{Deskripsi data 7}

Kalimat Berbahasa Indonesia

Mahasiswa Thailand (MT)

Kalimat Bahasa Melayu Pattani

Kalimat Bahasa Indonesia
: Ka? no? wa? tugas lu.

: Ka? no? wa? kijo lu.

: Kakak ingin membuat tugas dulu.
Pada data di atas, terdapat interferensi pada penggunaan BMP dalam berbahasa Indonesia mahasiswa Thailand di UMS, yaitu pada kata [ka? BMP dan [kakak] BI.
Dari data tersebut, terjadi interferensi fonologi melalui proses pelesapan suku kata yaitu pada kata [kakak] dalam BI menjadi [ $k a$ ?] dalam BMP.

\section{Deskripsi data 8}

Kalimat Berbahasa Indonesia

Mahasiswa Thailand (MT)

: Jam waps kits no? gi?

Kalimat Bahasa Melayu Pattani

Kalimat Bahasa Indonesia
: Puko waps kits no? gi?

: Jam berapa kita hendak pergi?
Pada data di atas, terdapat interferensi pada penggunaan BMP dalam berbahasa Indonesia mahasiswa Thailand di UMS, yaitu pada kata [gi] (BMP) dan [pergi] $(B I)$. Dari data tersebut, terjadi interferensi fonologi melalui proses pelesapan suku kata yaitu pada kata [pergi] dalam $(B I)$ menjadi [gi] dalam $(B M P)$. Di sini, terjadi pelesapan dua suku kata [pergi] menjadi satu suku kata $[g i]$.

Dari hasil analisis dan temuan data di atas, dapat dibuat perbandingan antara penelitian ini dengan penelitian-penelitian berikut.

Penelitian Joko (2011) yang berjudul 'Interferensi Bahasa Indonesia 
dalam Acara Berita Berbahasa Jawa "Kuthane Dhewe" di TV Borobudur Semarang' membahas terjadinya interferensi bahasa Indonesia dalam acara berita berbahasa Jawa"Kuthane Dhewe" di TV Borobudur Semarang, sedangkan penelitian ini berfokus pada interferensi BMP dalam BI oleh mahasiswa Thailand di UMS. Persamaan penelitian Joko dengan penelitian ini terletak pada hasil penelitian. Dalam hasil penelitian Joko, terdapat empat macam interferensi, yaitu (a) interferensi tataran fonologi, (b) interferensi tataran leksikal, (c) interferensi tataran morfologi, dan (d) interferensi tataran sintaksis, sedangkan penelitian ini menghasilkan interferensi fonologis saja.

Penelitian Annura (2013) yang berjudul "Interferensi Fonologi, dan Leksikal dalam Komunikasi Formal Mahasiswa Sastra Indonesia Fakultas Ilmu Budaya Universitas Airlangga" membahas terjadinya interferensi fonologi dan leksikal dalam komunikasi formal mahasiswa sastra Indonesia Fakultas Ilmu Budaya Universitas Airlangga, sedangkan penelitian ini berfokus pada interferensi BMP dalam BI oleh mahasiswa Thailand di UMS. Persamaan penelitian Annura dengan penelitian ini terletak pada hasil penelitian. Pada penelitian ini terdapat bahasan tentang fonologi dan leksikal.

Penelitian Masrurah (2000) yang berjudul "Interferensi Morfologis Penutur
Bahasa Bugis dalam Berbahasa Indonesia" membahas terjadinya interferensi morfologis penutur bahasa Bugis dalam berbahasa Indonesia, sedangkan penelitian ini berfokus pada interferensi BMP dalam BI oleh mahasiswa Thailand di UMS. Persamaan penelitian Masrurah dengan penelitian ini pada bahasan interferensi. Dalam penelitian ini, berhasil dikumpulkan data sosiolinguistik dalam bentuk data morfologis sebanyak 109 buah, 39 yang diolah menurut sifat-sifat morfemnya, kemudian ditranskripsikan untuk menemukan ruas-ruas asalnya.

Penelitian Laura, dkk. (2014) yang berjudul "Alih Kode, Campur Kode, dan Interferensi dalam Peristiwa Tutur Penjual dan Pembeli di Ranah Pasar Tradisional Cisanggarung Losari Kabupaten Brebes (Kajian Sosiolinguistik) "membahas terjadinya alih kode, campur kode, dan interferensi dalam peristiwa tutur penjual dan pembeli di ranah pasar tradisional Cisanggarung Losari Kabupaten Brebes, sedangkan penelitian ini berfokus pada interferensi BMP dalam BI oleh mahasiswa Thailand di UMS. Persamaan penelitian Lauradengan penelitian ini pada pembahasan tentang proses interferensi. Dalam penelitian ini, ditemukan interferensi bahasa Jawa dan bahasa Betawi pada tuturan bahasa Indonesia yang terjadi pada tataran fonologi, sintaksis, dan morfologi. 
Penelitian Stanislaus (2015) yang berjudul "Interferensi Bahasa Manggarai Timur terhadap BahasaIndonesia dalam Komunikasi Lisan Mahasiswa Manggarai Timur di Kota Malang" membahas terjadinya interferensi bahasa Manggarai Timur terhadap bahasa Indonesia dalam komunikasi lisan mahasiswa Manggarai Timur di Kota Malang, sedangkan penelitian ini berfokus pada interferensi BMP dalam BI oleh mahasiswa Thailand di UMS.

Keunikan dalam penelitian ini yaitu terdapat kata BMP dalam kalimat berbahasa Indonesia. Penelitian ini banyak memberi manfaat terhadap pemakai bahasa bilingual, terutama bagi penduduk Indonesia. Penduduk Indonesia dapat mempelajari dan kenal tentang BMP. Sebelumnya, mereka hanya mengenal bahasa Indonesia, tetapi sekarang mereka mengenal dan mempelajari BMP. Mereka dapat menguasai beberapa kosa kata BMP dan dapat berbicara dengan menggunakan BMP. Hal ini menunjukan bahwa mereka dapat menggunakan lebih dari satu bahasa secara bergantian.

\section{Penutup}

Penelitian ini menelaah masalah interferensi BMP dalam berbahasa Indonesia mahasiswa Thailand di UMS. Interferensi tersebut ditinjau dari segi wujudnya merupakan interferensi fonologi. Wujud interferensi BMP dalam berbahasa Indonesia mahasiswa Thailand di UMS dalam bentuk interferensi fonologi adalah sebagai berikut.

1. Penggantian fonem /a/ dengan fonem $/ \zeta /$, dan fonem $/ \gamma /$ dengan fonem $/ r /$, contoh pada kata $[$ kita] dalam (BI) yang menggunakan bunyi lal pada fonem akhir diganti dengan fonem / / pada suku kata akhir pada kata [kito] dalam BMP; dan pada kata [rumah] dalam (BI) yang menggunakan bunyi $/ r /$ pada fonem awal diganti fonem $/ \gamma /$ pada suku kata awal padakata [zumsh] dalam BMP.

2. Pelesapan fonem $/ n /$ pada suku akhir, contoh pada kata [dengan] dalam (BI) yang mempunyai fonem $/ n /$ pada suku kata akhir, dilesapkan dengan penghilangan fonem $/ n /$ pada suku kata akhir pada kata [denga] dalam BMP dan pada kata [akal] dalam (BI)yang mempunyai fonem /l/ pada suku kata akhir dilespkan dengan penghilangan fonem /l/ pada suku kata akhir pada kata $[a k a]$ dalam BMP.

3. Penggantian suku kata /lan/ diganti dengan /le/, dan suku kata /lam/ diganti $/ l \varepsilon /$, contoh pada kata [jalan] dalam (BI) yang menggunakan suku kata /lan/ pada suku akhir, diganti suku kata /le/ pada suku akhir kata pada kata [jale] dalam 
BMP dan pada kata [dalam] dalam (BI) yang menggunakan suku kata /lam/ pada suku akhir, diganti suku kata / $l \varepsilon$ / pada suku akhir kata pada kata [dale] dalam BMP.

4. Pelesapan suku kata [kakak] diganti [ka?], contoh pada kata [kakak] dalam (BI) menjadi [ka?] dalam (BMP) dan pada kata [pergi] dalam (BI) menjadi [gi] dalam (BMP).

\section{Daftar Pustaka}

Al-Fatoni, Ahmad. (2001). Pengantar Sejarah Pattani. Kota Bahru Malaysia: Pustaka Aman Press Sendirian Berhad.

Alwasilah, Chaedar A. (2011). Linguistik Suatu Pengantar. Bandung: Angkasa.

Annura Wulan, Darini. (2013). "Interferensi Fonologi, Morfologi, dan Leksikal dalam Komunikasi formal Mahasiswa Sastra Indonesia Fakultas Ilmu Budaya Universitas Airlangga”. Jurnal Skripporium, Vol. 1. No. 3. 2013, hal, 7--16.

Chaer, Abdul \& Agustina. (2010). Telaah Bibliografi Kebahasaan Bahasa Indonesia/Melayu. Jakarta: Rineka Cipta.

Kridalaksana, Harimurti. (1985). Tata Bahasa Deskripsi Bahasa Indonesia: Sintaksis. Jakarta: Pusat Pembinaan dan Pengembangan Bahasa Departemen Pendidikan dan Kebudayaan.

Laura Rhosyantina, Zamzani \& Maslakhah, Siti. (2014). "Alih Kode, Campur Kode, dan Interferensi dalam
Peristiwa Tutur Penjual dan Pembeli di ranah Pasar Tradisional Cisanggarung Losari Kabupaten Brebes (Kajian Sosiolinguistik)". Bahasa dan Sastra Indonesia, Vol. 3. No. 3. 2014.

Mokhtar, Masrurah. (2000). "Interferensi Morfologis Penutur Bahasa Bugis dalam Berbahasa Indonesia”. Jurnal Humaniora: Journal of Culture, Literature, and Linguistic, Vol. 12. No. 2. 2000.

Nababan. (1991). Sosiolinguistik Suatu Pengantar. Jakarta: PT Gramedia Pustaka Utama.

Ngalim, Abdul. (2013). Sosiolinguistik: Satuan Kajian Fungsional dan Analisisnya. Solo: PBSID FKIP UMS.

Ohoiwutun, Paul. (1996). Sosiolinguistik. Jakarta: Kesaint Blance.

Pateda, Mansoer. (1987). Sosiolinguistik. Bandung: Angkasa.

Ramlan, M. (1985). Tata Bahasa Indonesia: Penggolongan Kata. Yogyakarta: Andioffset.

Ramlan, M. (2001). Ilmu Bahasa Indonesia: Sintaksis. Yogyakarta: CV Karyono.

Stanislaus, Hermaditoyo. (2015). "Interferensi Bahasa Manggarai Timur terhadap Bahasa Indonesia dalam Komunikasi Lisan Mahasiswa Manggarai Timur Kota Malang”. Nosi, Vol. 3. No. 1 Agustus 2015, hal. 105.

Sukoyo, Joko. (2011). "Interferensi Bahasa Indonesia dalam Acara Berita Berbahasa Jawa "Kuthane Dhewe" di TV Borobudur Semarang". Lingua Jurnal Bahasa dan Sastra, Vol. 7. No. 2. 2011, hal, 95 
